\section{EDITORIAL BOARD}

Editor and Chair

Mary Beth Weber, Rutgers University

\section{Members}

Jennifer Bazeley, Miami University

Lisa B. German, University of Houston

Sylvia Hall-Ellis, Colorado Community College System

Kathlene Hanson, California State University Monterey Bay

Karen E. Kiorpes, State University of New York-Albany

Forrest Link, College of New Jersey

Margaret Mering, University of

Nebraska-Lincoln

Jeremy J. Myntti, University of Utah Carol Ou, University of Nevada, Las Vegas

Brian A. Quinn, Texas Tech

University

Lori Robare, University of Oregon

Chelcie Rowell, Wake Forest

University

George Stachokas, Auburn

University

Mary Van Ullen, State University of New York-Albany

Sherry Vellucci, University of New Hampshire

Virginia Kay Williams, Texas State University

Oksana Zavalina, University of North Texas

\section{Ex-Officio Members}

Elyssa M. Gould,

Book Review Editor, LRTS

Rebecca Mugridge,

State University at Albany

Editor, ALCTS News

Keri Cascio, Executive Director, ALCTS

Brooke Morris, Communications Specialist, ALCTS

\title{
Guest Editorial: The Pivot to E
}

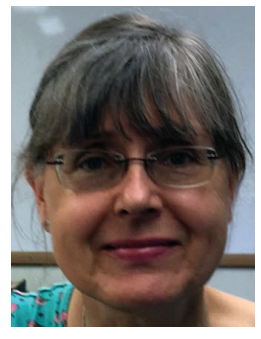

\section{Michele Seikel}

Michele Seikel (michele.seikel@okstate.edu) is Associate Professor and Serials Cataloger at the Edmon Low Library, Oklahoma State University, Stillwater, Oklahoma. Seikel served two terms as a member of the Library Resources and Technical Services editorial board, and I am pleased to provide her guest editorial to share her perspective on the evolving role of digital resources and its continued impact on technical services work.

T n 2004, Deanna Marcum, associate librarian for library 1 services at the Library of Congress (LC), gave an address titled "The Future of Cataloging" in which she detailed the many ways that the Internet had already changed research for students. She asked whether, in light of the increasing power of search engine indexing, digital resources should receive the same careful, detailed bibliographic description as printed materials. At that time, Google and several large research libraries were involved in the massive digitization project that became Google Books. Since then, other large digitization projects have combined to produce full-text digital versions of a great deal of the contents not under copyright of many research libraries.

The address drew an angry response from another LC librarian, Thomas Mann, who described Marcum's paradigm as "an inappropriate business model," asserting that scholars are the niche market that library cataloging is intended to satisfy, not students. Mann, a reference librarian, was particularly concerned with the idea of eliminating LC faceted subject headings from records.

In the years since, much has changed in the world of bibliographic description, and in a broader sense, library collections in general. Millions of records for digital materials have been added to OCLC WorldCat and to our local catalogs. In those local catalogs and databases, we routinely provide full-text links to government documents, books, and serials that were only available in print collections a few years ago. Many libraries that have access to those digitized materials are in the process of moving print collections to storage or weeding them. Fields, codes, and FAST subjects have been batch-added to millions of records in OCLC's enormous database. Our many e-resources have millions of mostly vendor-created records to describe them, which we batch-load into our catalogs and sometimes edit as best we can. In our pivot toward e-resources, we have tried not to throw all the babies out with the print bathwater.

But our bathtub has changed shape around us in response to our society's increasing dependence on Internet-ready devices, a development that cannot be ignored. The pivot to e-resources has necessitated cataloging, acquisitions, and collection management librarians to learn new skills and abandon old ones. Positions that focused on twentieth-century methods of acquiring, processing, and cataloging physical materials are vanishing. New staff are being hired to focus mostly on making online materials accessible. This is a massive, historic shift, disproportionately affecting technical services librarians and staff, and no one argues about whether it is good or bad anymore-we really do not have time.

Against this rapidly changing background, what are the concerns of those who still have the luxury of doing research and publishing it in peer-reviewed journals? Of the twenty-seven papers published in this journal since 2014, twenty-two addressed e-resources in some way. Some of the most common 
topics have been digital preservation methods, metadata, and e-resource acquisitions. Our research choices illustrate our most pressing concerns.

This issue includes papers concerning BIBFRAME, name authorities, and migration to Alma. So then, what has not changed? Libraries continue to maintain local catalogs, and they still find name authority records useful for distinguishing similar names from each other. And, as more materials are digitized or created online, technical services work will continue. But, increasingly, it involves creating or acquiring access to those handy full-text links, making them findable, and maintaining them for our users.

\section{References}

1. Deanna B. Marcum, "The Future of Cataloging" (address to the EBSCO Leadership Seminar, Boston, January 16, 2004), www.guild2910.org/marcum.htm.

2. Thomas Mann, The Changing Nature of the Catalog and Its Integration with Other Discovery Tools, Final Report, March 17, 2006, Prepared for the Library of Congress by Karen Calhoun: A Critical Review, https://www.loc.gov/catdir/calhoun -report-final.pdf.

\section{A R C H I VA L PRODUCTS}

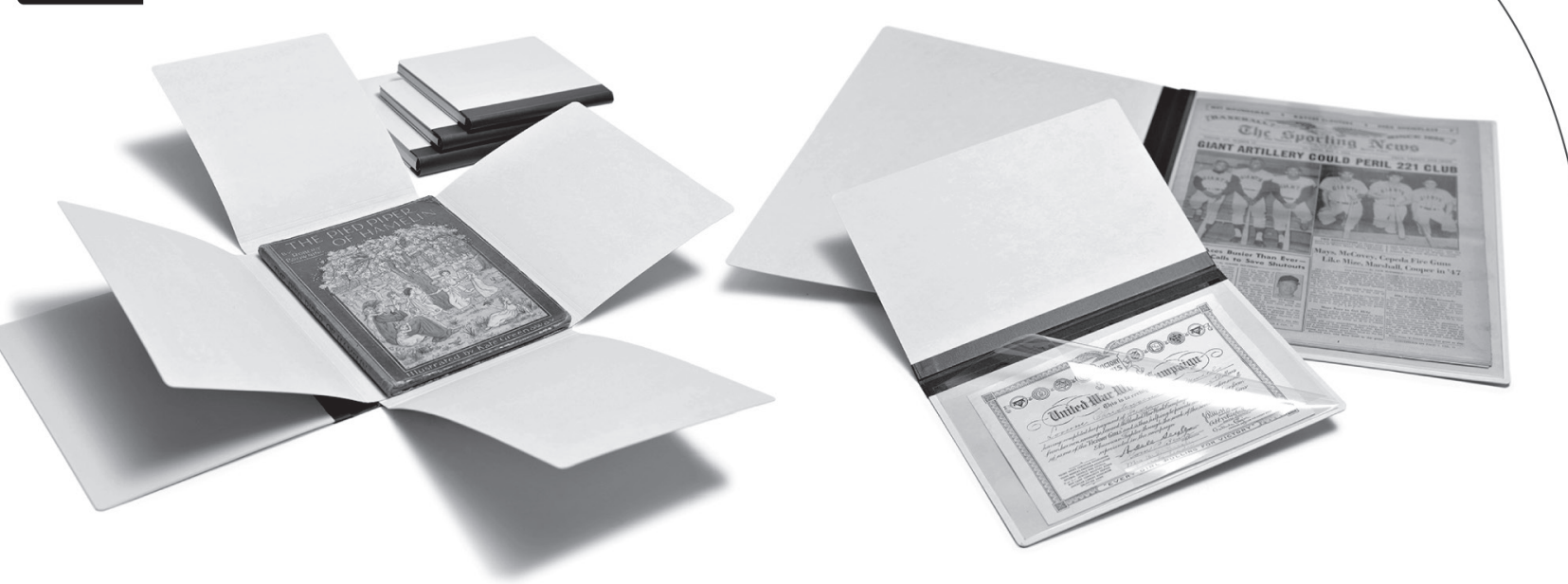

\section{Preserve + Conserve + Quality}

It's who we are, and what we deliver.

At Archival Products, we care about preserving your most important items. That's why we've developed an extensive product line to meet virtually every preservation need. All hand-crafted by our dedicated team. 